AperTO - Archivio Istituzionale Open Access dell'Università di Torino

Rethinking Regenerative Medicine from a Transplant Perspective (and Vice Versa)

This is a pre print version of the following article:

Original Citation:

Availability:

This version is available http://hdl.handle.net/2318/1694661

since 2019-03-11T19:44:05Z

Published version:

DOI:10.1097/TP.0000000000002370

Terms of use:

Open Access

Anyone can freely access the full text of works made available as "Open Access". Works made available under a Creative Commons license can be used according to the terms and conditions of said license. Use of all other works requires consent of the right holder (author or publisher) if not exempted from copyright protection by the applicable law. 


\section{Rethinking regenerative medicine from a transplant perspective (and vice versa)}

Giuseppe Orlando ${ }^{1}$, Sean Murphy
,
Clancy $^{4}$, Paolo Cravedietta Bussolati

${ }^{1}$ Wake Forest University School of Medicine, Department of Surgery, Section of Transplantation, Winston Salem, USA

${ }^{2}$ Wake Forest Institute for Regenerative Medicine, Winston Salem, USA

${ }^{3}$ Department of Molecular Biotechnology and Health Sciences, University of Turin, Turin, Italy

${ }^{4}$ Transplant Unit, Queen Elizabeth University Hospital, Glasgow, UK

${ }^{5}$ Translational Transplant Research Center, Department of Medicine, Icahn School of Medicine at Mount Sinai, New York, NY

${ }^{6}$ Consorzio per Valutazioni Biologiche e Farmacologiche, Bari, Italy

${ }^{7}$ Department of Cellular and Molecular Physiology, Centre for Preclinical Imaging, Institute of Translational Medicine, University of Liverpool, Liverpool, UK

Disclosure: authors have no conflicts of interest to disclose

Referral author: $\quad$ Giuseppe Orlando, $\mathrm{MD}, \mathrm{PhD}$, Marie Curie Fellow Wake Forest University Health Sciences

Department of Surgery, Section of Transplantation

Winston Salem, NC, USA

Tel: +1 3367166903

Email: gorlando@wakehealth.edu 


\section{Authorship}

Giuseppe Orlando conceived the work and the design of the manuscript, was responsible for its undertaking and completion, wrote the introduction, the paragraph on decellularization technology and the conclusions and approved the final draft

Sean Murphy participated to the design of the manuscript, wrote the part on 3D printing and approved the final draft

Benedetta Bussolati participated to the design of the manuscript, wrote the part on stem cells, regeneration and blastocyst complementation, and approved the final draft

Marc Clancy participated to the design of the manuscript, wrote the part on ischemiareperfusion and approved the final draft

Paolo Cravedi wrote the part on the immunology of biomaterials and approved the final draft

Giovanni Migliaccio wrote the part on product development and translation, and approved the final draft

Patricia Murray participated to the design of the manuscript, wrote the part on stme cells, regeneration and blastocyst complementation, and approved the final draft 


\begin{abstract}
No field in health sciences has more interest than organ transplantation in fostering progress in RM because the future of no other field more than the future of organ transplantation will be forged by progress occurring in RM. In fact, the most urgent needs of modern transplant medicine - namely, more organs to satisfy the skyrocketing demand and immunosuppressionfree transplantation -, cannot be met in full with current technologies and are at risk to remain elusive goals. Instead, in the past few decades, groundbreaking progress in regenerative medicine $(\mathrm{RM})$ is suggesting a different approach to the problem. New, RM-inspired technologies among which decellularization, 3D printing and interspecies blastocyst complementation, promise organoids manufactured from patients' own cells and bear potential to render the use of currently used allografts obsolete. Transplantation, a field that has traditionally been immunology-based, is therefore destined to become a RM-based discipline.

However, the contours of RM remain unclear, mainly due to the lack of a universally accepted definition, the lack of clarity of its potential modalities of application and the unjustified and misleading hype that often follows the reports of clinical application of RM technologies. All this generates excessive and unmet expectations and an erroneous perception of what RM really is and can offer.

In this manuscript, we will reason on these aspects of RM and transplant medicine, will propose a definition of RM and will illustrate the state of the art of the most promising RMbased technologies of transplant interest.
\end{abstract}




\section{Introduction}

Regenerative medicine (RM) has shown an immense potential to profoundly impact transplant medicine (TM) by meeting its two most urgent needs: a new and potentially inexhaustible source of organs and the achievement of an immunosuppression-free status[1]. Through the development of technologies that will make organ fabrication possible using patient-derived biomaterials - cells and supporting scaffolding materials - RM promises to enable organ-on-demand whereby patients will receive organs that will not be rejected and in a timely fashion. This will make registration in the waiting list and anti-rejection medications unnecessary and, as the new organs will be implanted immediately after fabrication, ischemia-reperfusion injury secondary to organ preservation will not be a problem anymore. However, the contours of RM remain unclear, mainly due to the lack of a universally accepted definition, the lack of clarity of its potential modalities of application and the unjustified and misleading hype that often follows the reports of clinical application of RM technologies. All this generates excessive (and unmet) expectations and an erroneous perception of what RM really is and can offer.

With the present manuscript, we intend to address these concerns, propose a definition of RM pertinent to TM and elucidate the RM technologies that may be applied to and serve the mission of TM. We will also briefly discuss the most relevant product development challenges and the immunological implications of the biomaterials currently under development.

\section{Definition}

"Regenerative medicine" is an umbrella term of still unclear significance. For example: in 2006 the United Nations Educational, Scientific and Cultural Organization (UNESCO) defined RM as a superdiscipline whose contours are still being defined (http://unesdoc.unesco.org/images/0014/001454/145409e.pdf). In the document, it was stated that the definition of RM "can be either narrow or very wide" and that the field "is generally about replacement, repair and regeneration to address deficient organ function resulting from congenital defects, disease, trauma or wear and tear". From this definition, it may be inferred that RM and TM share the same interests and pursue the same goal, namely the replacement of terminally diseased organs with new functioning organs. However, while the term replacement is intimate to organ transplantation, repair and regeneration are not, unless we consider the case of auxiliary heterotopic liver transplantation, performed to allow the native liver devastated by an acute damage to regenerate and resume normal function[2]. 
More recently, the term RM has been used to define - more succinctly - a field in the health sciences that aims to replace or regenerate human cells, tissues, or organs to restore or establish normal function[3]. The process of regenerating body parts can occur in vivo or ex vivo and may require cells, natural or artificial scaffolding materials, growth factors, gene manipulation, or combinations of all the four elements. However, RM is commonly used as synonymous to "tissue engineering", but it has been noted that "tissue engineering" is "narrower in scope and strictly defined as manufacturing body parts ex vivo, by seeding cells on or into a supporting scaffold"[4]. According to NIH, "tissue engineering evolved from the field of biomaterials development and refers to the practice of combining scaffolds, cells, and biologically active molecules into functional tissues", with the ultimate goal of assembling "functional constructs that restore, maintain, or improve damaged tissues or whole organs" (https://www.nibib.nih.gov/science-education/science-topics/tissue-engineeringand-regenerative-medicine ).

The NIH also defines RM as "the process of creating living, functional tissues to repair or replace tissue or organ function lost due to age, disease, damage, or congenital defects. This field holds the promise of regenerating damaged tissues and organs in the body by stimulating previously irreparable organs to heal themselves; [...] empowers scientists to grow tissues and organs in the laboratory and safely implant them when the body cannot heal itself. Importantly, regenerative medicine has the potential to solve the problem of the shortage of organs available through donation compared to the number of patients that require life-saving organ transplantation". (https://report.nih.gov/nihfactsheets/viewfactsheet.aspx?csid=62). This definition is quite comprehensive but neglects two critical aspects of modern TM, namely immunosuppression-free transplantation and ischemia-reperfusion damage deriving from organ preservation and storage. In fact, RM research aims at building autologous tissues and organs from patient's own cells with the ultimate goal of bypassing the need for lifelong anti-rejection therapy, with consequent obvious clinical and financial benefits. Moreover, by enabling physicians to implant bioengineered organs immediately after maturation, ischemia-reperfusion damage is prevented.

Last, to the best of our knowledge, none of the societies that may claim parenthood to the field of RM has ever released an official definition of the term. Therefore, we herein propose the following definition:

$R M$ is a field in the health sciences that aims to regenerate, repair or replace functionally impaired tissues and organs in order to restore normal function. The process of regenerating body parts can occur in vivo or ex vivo and may require cells, natural or artificial scaffolding materials, growth factors, genetic manipulation, or combinations of them. RM promises to address the longest standing limitations of organ transplantation, namely the identification of an inexhaustible source of transplantable organs, immunosuppression-free transplantation and organ-on-demand, whereby a patient in need and deemed suitable for transplantation is enabled to promptly receive an organ that 
will be bioengineered from his/her own cells. This will rule out the need for lifelong immunosuppression and, by allowing implantation of the graft immediately after production, will likely prevent the damage resulting from organ preservation, storage and ischemia-reperfusion. As a corollary, RM will eliminate the waiting list.

\section{RM technologies applied to organ transplantation}

Decellularization. The term decellularization refers to a process whereby the cellular compartment of living tissues is removed by chemical or physical means[5]. The end product of this process is an acellular scaffold consisting of the innate extracellular matrix (ECM) of the original tissue that is being used for different purposes. For example, acellular scaffolds may serve as template for the ex vivo bioengineering of implantable organs[6], or to promote functional tissue restoration after implantation in vivo[7]. In the first case, the scaffold will be recellularized with progenitor or adult cells first, and either allowed to mature in bioreactors before implantation or implanted directly in patients thereafter [8]. In the second case, the acellular scaffold is implanted in the diseased tissue to orchestrate a constructive remodeling in situ[7]. The rationale behind these applications is that the ECM is the fundamental $3 \mathrm{D}$ network that not only provides structural support to cells, but by interacting with cell surface molecules and serving as a reservoir for growth factors, also plays a critical role in tissue and organ development, homeostasis and regeneration after damage[9]. Although the decellularization process does produce some damage to the innate ECM, the scaffolds produced with current technology retain most of the biochemical complexity, nanostructure, and bioinductive properties of the native matrix that are essential for cells to attach, migrate, proliferate and function, and have been shown to promote the creation of site-specific, functional tissue in vivo[10]. Moreover, as the framework of the innate vasculature is preserved, patent, and able to sustain the physiological blood pressure[11], acellular ECM scaffolds (aECMs) seem ideal for the bioengineering of transplantable organs. AECMs may also be a source of hydrogel and used as such as cell delivery tool. Notably, more than 80 ECM based products are currently available in the market for a variety of clinical applications[12].

From a TM perspective, the use of aECMs as a template for whole organ bioengineering undoubtedly holds immense potential. Since the milestone report on the bioengineering of a functional heart in 2008[13], more than two hundreds papers have proven that aECMs may be produced from virtually all transplantable organs from clinically relevant animal [11, 14-16] and human donors [16-24], including the human hand, face and face subunits [25-29]. As one of the major objectives of RM is to identify an inexhaustible source of organs, animals may be considered an ideal source of aECMs for intra-abdominal and intra-thoracic bioengineering, whereas human donors should provide organs for limb, face and face subunit bioengineering for obvious reasons. Interestingly, the term semi- 
xenotransplantation has been proposed to indicate the bioengineering of implantable organs whereby aECMs of animal origin are seeded with human cells [30].

Despite the fact that viable and functioning bioengineered tissues and/or organs supplied with their own vascular pedicle have never previously been described in animal models, the literature reports a few anecdotal cases [8, 24, 31-34] or small studies in humans [35] where relatively complex tissues were transplanted without any vascular pedicle, and therefore lacked an immediate connection to the recipient's vasculature. Although some short-term success has been obtained, and to some extent, it can be claimed that the proof of concept has been provided, the reported morbidity and mortality are extremely high [36]. This probably reflects our incomplete understanding of the biology of organ regeneration and underestimation of the true anatomical and physiological complexity of the organs in question[37]. As recently stigmatized by Badylak in an illuminating editorial, the big mistake that has been reiterated by tissue engineers in the past decade is the erroneous belief that organs can be manufactured without the critical elements required to maintain the viability and function of all living tissues; namely, adequate lymphatic and innervation networks, and - more importantly vascularization [38]. Moreover, most clinical and experimental studies report that after cells are seeded on aECMs, the so-obtained construct is allowed to mature in bioreactors for conventional periods of one or few weeks, which is probably insufficient as this is much shorter than the time needed for any given organ to develop in utero.

3D printing technology. 3D bioprinting promises to have a disruptive impact in TM and represents a significant technological advancement in the manufacturing processes used for tissue and organ engineering. Where the conventional manufacturing approach requires the manual fabrication by a skilled technician, 3D bioprinting is automating this process, with subsequent improvements in standardization, reproducibility, resolution and accuracy. These advances have arisen from the adoption of design and manufacturing techniques used in the non-biological manufacturing sector, such as the use of imaging and design software, and the increased availability, and reduced cost of 3D printing hardware. 3D printed medical devices have already been transplanted into patients [39, 40], and simple bioprinted tissues such as cartilage and bone have been successfully transplanted in preclinical animal studies [41-43]. However, just like above, current 3D bioprinted tissues lack essential functional elements such as vasculature, innervation, lymphatics and the number and diversity of functional and supporting cell types required for more complex or larger tissues and organs.

In health care, 3D printing has been applied for the manufacturing of surgical guides, anatomical models and prosthetics [39], and more recently, for custom implants [44]. Medical uses of 3D printing have usually been confined to static, non-living constructs, including patient-specific craniofacial implants and hip and mandibular prostheses [40]. In 2013, the clinical application of 3D printing was 
expanded, with the implantation of a 3D printed, bioresorbable external airway splint into an infant with tracheobronchomalacia, which was followed up with a 2015 report of a further 3 infants recei

ving patient-matched 3D printed splints [45]. These constructs, while non-living, were designed to prevent external airway compression over a predetermined time period before bioresorption to accommodate airway growth [46]. While these advances have demonstrated the promise of 3D printing technology for medical applications, the progression from non-living constructs to $3 \mathrm{D}$ printed living cellular constructs has not been as rapid. Significant challenges surrounding the formation of complex, heterogeneous tissues, with sufficient vasculature, innervation, and function, means that we are currently years away before even simple constructs make their way into clinical use. It is likely that the first advances in the clinical transplantation of 3D printed living tissues will be made in relatively simple tissues before advancing to tissues with more complex geometries, cell types and functions.

In contrast to many other tissues, cartilaginous tissues are avascular and aneural structures containing a relatively low density of cells, potentially minimizing three of the most difficult hurdles in the field. For this reason, cartilaginous tissues are likely to be one of the first types of 3D printed tissues to progress to clinical transplantation, and multiple examples of 3D printed cartilage tissue have been described at the pre-clinical stage of development. Cui and colleagues have applied inkjet 3D printing technology to repair human articular cartilage [41], achieving a tissue construct with a compressive modulus in the same order of magnitude as hyaline cartilage [47].

Another novel approach involves the fabrication of tissue constructs using self-assembling spheroids of chondrocytes to form cartilage strands, significantly increasing cellular density and improving post-transplantation maturation and function [48]. Recently, the biofabrication and implantation of human-sized 3D printed cartilage tissues has been reported, with tissue constructs possessing histological and mechanical characteristics of human auricles after animal implantation in vivo [49].

Bone has been well studied by the materials engineering community due to its unique structure and mechanical properties. Biomaterial scaffolds that exploit the inherent properties of nanoparticles have been developed that meet the physicomechanical requirements of bone regeneration, formulated to control the mechanical properties and degradability of scaffolds upon transplantation [50]. In one example, Inzana and coworkers fabricated a calcium phosphate, collagen composite bone scaffold using a modified inkjet-based 3D printer. The implants were confirmed to be osteoconductive and biodegradable in a critical sized murine femoral defect [43]. However, to date, many 3D printing approaches rely only on hard scaffolds to reproduce the appropriate mechanical properties for cortical bone, but fail to fully recapitulate the cellular, spongy component of cancellous bone. One approach to overcome this limitation includes incorporating bone marrow-derived mesenchymal stromal cells into osteoconductive hydrogel bioinks. These soft bioinks are then supported by a network of reinforcing poly( $\varepsilon$-caprolactone) (PCL) microfibers to enable the fabrication of mechanically 
reinforced constructs with decoupled biological and mechanical functionality. These 3D printed constructs mimic the geometry and bulk mechanical properties of trabecular-like endochondral bone with a supporting marrow structure, and undergo endochondral ossification over time following implantation [51]. Using a similar approach, human-scale mandible and calvarial structures have been 3D printed, with size and shape similar to what would be needed for facial reconstruction after traumatic injury. Implantation of 3D printed bone constructs into animal defect models resulted in the formation of mature, vascularized bone tissue in implants retrieved up to 5 months later [49].

The application of $3 \mathrm{D}$ printing technology to fabricate relatively simple tissues such as cartilage and bone has been facilitated by the development of new biomaterials and 3D printing technology that can accurately and reproducibly deposit these materials. 3D bioprinting techniques can be broadly classified by their mechanism of cell deposition into inkjet [52], microextrusion [49, 53-55], or laserassisted bioprinting [56-58]. The basic technologies and their applications have been extensively reviewed $[59,60]$. Recent advances in bioprinter technology have facilitated the patterning of multicomponent constructs containing both synthetic and natural materials capable of resolution down to $2 \mu \mathrm{m}$ for biomaterials alone and down to $50 \mu \mathrm{m}$ for encapsulated cells [49]. Further progress in the field will require the ability to deposit an even wider range of material types concurrently with increases in print resolution and speed. Some progress has been made in this area, such as the use of microfluidic switching nozzles that swap between two different inks on demand [61], as well as mixing nozzles that can be used to print materials at the microscale with tunable gradients of differing material properties [62]. Additionally there has been remarkable achievements in the high-resolution patterning of matrix materials using light-based free-form fabrication. One example of this is twophoton lithography, where transparent photoresist materials are photopolymerized with multiphoton absorption events with highly controllable focal volumes and print speed [63].

The combination of materials that provide mechanical strength and those that are compatible with cell function has resulted in the successful fabrication of human scale, cellular tissues that have shown long-term function post-transplantation. Biomaterials commonly used for bioprinting are predominantly based on either naturally derived polymers (such as tissue-based extracellular matrix proteins including alginate, gelatin, collagen, chitosan, fibrin and hyaluronic acid) or synthetic molecules (polyethylene glycol; PEG). Often, the synthetic materials provide physical integrity at the at the macro level, while softer materials, such as hydrogels, provide an appropriate environment for cell encapsulation and placement. However, synthetic materials often fail to provide physiological interactions with the cellular component. On the other hand, the weak mechanical properties of hydrogels is a considerable limitation for their contribution to the physical properties of the tissue. Further advances in the development of biological materials are needed to improve control of the structural, mechanical, and biological properties of constructs to replicate tissue structure and function $[64,65]$. One approach towards overcoming this challenge include chemical modification of the hydrogels to enable the materials to cross-link with other materials, therefore controlling its 
mechanical strength or other parameters such as degradation times. Synthetic hydrogels like PEGbased hydrogels have been modified to covalently tether ECM-derived biomolecules [66]. Similarly, there is a need for the continued development of 3D printers that are specifically designed for these biological materials, combined with the decreased cost of these technologies.

However, before we can expect to see successful 3D printing of larger, or more complex tissue types, several significant limitations and obstacles need to be overcome. For larger tissues, the incorporation of intact vasculature will be essential for the survival and function of the implanted tissues. One potential approach to overcome this bottleneck is the utilization of light-based 3D printing technology, capable of photopolymerizing a wide range of biological materials, with significantly improved speed and resolution. For example, microscale continuous optical bioprinting $(\mu \mathrm{COB})$ has been used to create prevascularized tissue constructs within a soft hydrogel network [67]. The ability to pattern increasingly complex cellular structures with increased resolution would provide many opportunities to incorporate other functional tissue components and architectures such as vascular, neural and lymphatic networks and potentially lumens, tubules and ducts. Another limitation to the fabrication of larger, more complex tissues is the requirement for increased quantity and diversity of cell types. Many studies have utilized either primary cells or tissue-derived multipotent stem cells, but the limited expansion and differentiation capacity of these cell types may limit their application for larger or more complex tissues. Potential approaches to overcome this problem include involve viral transfection [68] or use of small molecules to induce cell proliferation or differentiation $[69,70]$.

Stem cell technology. Cells within the inner cell mass of blastocyst-stage embryos give rise to all adult cell types and are thus termed 'pluripotent'. In 1981, it was discovered that these 'embryonic stem cells' (ESC) could be isolated from mouse embryos and expanded in culture without losing their pluripotency [71]. Following the isolation of the first human ESC lines in 1998 [72], there was huge optimism that these cells could not only replace cells lost in degenerative diseases such as Parkinson's disease, but could also be combined with natural or bioengineered scaffolds to generate replacement tissues and organs [73]. However, apart from the ethical issues surrounding the use of human embryos, several challenges facing the development and application of ESC-based therapies were soon identified, including (i) their tumorigenic risk; (ii) the need for reliable culture conditions to direct their differentiation to fully functional specialized cells; (iii) strategies to prevent immunerejection.

Much progress has been made; for instance, methods to identify and remove undifferentiated ESCs from administered cell populations have now been developed [74], reducing the risk of tumor formation; and although some ESC derivatives remain functionally immature [75, 76], others, such as ESC-derived retinal pigment epithelial cells, display the typical characteristics of their adult counterparts [77] and have already been applied in clinical trials [78]. Some ESC-based therapies can 
involve the transplantation of progenitor cells which then further differentiate in vivo to generate functionally mature cell types; for example, ESC-derived dopaminergic neuron progenitors can undergo maturation in rats with chemically-induced Parkinson's disease and can ameliorate motor deficits [79]. The problems with immune-rejection, however, still remain, because ESC are nonautologous. Therefore, unless ESC-based therapies are applied to immune-privileged sites like the retina and brain, immune-suppressant therapies or other strategies to prevent immune-rejection are required.

Reports that pluripotent stem cells could be isolated from bone marrow[80] appeared to circumvent the aforementioned ethical issues as well as the problems with immune-rejection, as these cells can be self-derived. Although it is now clear that the bone marrow does not harbor pluripotent stem cells, there is good evidence that multipotent mesenchymal stromal cells (MSC) isolated from various sources, including bone marrow, adipose tissue and umbilical cord, have the potential to generate bone-, cartilage- and adipocyte-like cells following in vitro culture under specific conditions [81]. This has led to much enthusiasm regarding the use of autologous MSC-derived cells in combination with biomaterial scaffolds to generate replacement tissues for transplantation, an example being the use of MSC-derived chondrocytes to regenerate cartilage in the upper airway [24]. However, although such constructs have been used in human patients under 'compassionate use', data from animal studies indicate that MSC-derived chondrocytes fail to engraft and there is no evidence of cartilage regeneration [82], which might partly explain the high mortality rates observed in the clinic [83]. Most studies now show that while MSC and other somatic cell-based regenerative medicine therapies can have significant beneficial effects, these are mediated by paracrine factors that either directly or indirectly stimulate endogenous repair [84-86]. Thus, while MSC could be useful for promoting the repair and regeneration of transplanted tissues and organs, it is unlikely that they will be able to directly replace damaged tissues [87]. For instance, liver MSC-derived exosomes administered in an ex vivo normothermic liver perfusion system displayed regenerative functions and promoted in vivo repair [88].

The seminal work of Yamanaka, who showed that somatic cells could be reprogrammed to generate induced pluripotent stem cells (iPSC) that have the same plasticity as ESC [89, 90], addressed some of the problems encountered with ESC and MSC; for instance, iPSC generation does not require human embryos, they can be patient-derived, and unlike MSC, they are pluripotent. The plasticity of iPSC raises the possibility that they could be used as a source of specialized cells types for the recellularization of tissue and organ scaffolds for transplantation. Indeed, iPSC appear to represent a potentially unlimited supply of pluripotent cells that could overcome cellular challenges related to quantity and specificity of cell sources for recellularization [91]. Improvement in pluripotent stem cell differentiation techniques are continuously in development [92]. Further optimization has to be determined exploiting the local cues and the functional stimuli occurring in the in vivo setting to acquire functional maturation. While some progress has been made with de- and 
recellularization of kidney [93], heart [21], pancreas [94] and liver scaffolds [95], at present an adequate kidney scaffold recellularization in vivo appears challenging and available infusion protocols inadequate [96].

Overall, several additional key points need to be clarified to make stem cell research more realistic and practical. The extent and quality of vascularization required by tissue-engineered constructs for their in vivo stabilization and maintenance still need to be determined [97]. RM would benefit of methods to allow a constant in vivo tracking of cell viability and functions. Magnetic resonance imaging and optical imaging appear the more suitable approaches for high spatial resolution and high sensitivity, respectively. A fist approach to track endothelial after seeding in a trachea scaffold has been recently reported using bioluminescence technology cells [98].

Organoids and blastocyst complementation. Apart from the potential of using iPSC in combination with scaffolds for tissue replacement, recent progress has been made towards generating 3dimensional iPSC-derived organoids in vitro representative of several different organ systems, including renal, liver and heart organoids [99]. Exciting breakthroughs have been made with renal organoid development in particular, where it has been shown that iPSC-derived renal progenitor cells can generate organoids comprising all key renal cell types [100]. While organoids could potentially open the door to the development of bioengineered tissues and organs for transplantation in the future, many problems first need to be overcome, including appropriate vascularization. This is actually a major challenge because in the developing embryo, the major organ systems develop together with their capillary network and main feed arteries, ensuring that blood is supplied at the correct pressure. This problem is exemplified by a previous study showing that fetal rat kidneys do not mature beyond a neonatal stage following transplantation into adult rats, likely due to their abnormal vasculature and failure to develop a renal artery [101].

A potentially more promising iPSC-based technology for generating autologous tissues and organs for transplantation is interspecies blastocyst complementation (IBC). In this approach, genetic manipulation of the host precludes the development of an organ which is then compensated by stem cells from a donor that produce the missing organ. Proof of principle for this approach was demonstrated in 1993 to generate $\mathrm{T}$ and $\mathrm{B}$ lymphocyte lineages by implanting murine ESC into the blastocysts of $\mathrm{Rag}^{-/-}$mice [102]. Using host blastocysts derived from Pdx1-/- mice that display pancreatic agenesis, Melton's group showed that complementation with wild-type mouse ESCs resulted in the pancreatic epithelium being derived from the donor $P d x 1+/+$ cells [103]. A later study showed that complementation of $P d x 1$-/- mouse blastocysts with rat iPSC resulted in the development of functional rat pancreases within the adult mice hosts, thus demonstrating interspecies complementation [104]. These groundbreaking studies raise the possibility that, by genetically modifying pig blastocysts so that they are unable to generate specific organs, and then complementing with patient-derived human iPSC, it could be possible to generate autologous organs for 
transplantation within the host pig. A key advantage of this approach is that apart from being autologous, functional and of the correct size, the organs could be transplanted with their own vascular pedicle. However, a number of challenges need to be addressed. For instance, although rat iPSC could generate pancreata within mouse hosts, they were unable to generate kidneys in Sall-/mice that display renal agenesis [105], suggesting that for some organs, additional modification of the donor iPSC might be required to enable them to interact appropriately with the developing host embryo. Furthermore, previous attempts to undertake interspecies complementation using human pluripotent stem cells and mouse blastocysts have had limited success [106, 107]. Nevertheless, using a 'primed' pluripotent state, Belmonte's group has shown that human pluripotent stem cells could contribute to developing mouse embryos following grafting into gastrulating mouse embryos [108], thus providing proof of principle for interspecies blastocyst complementation using human iPSC. Importantly, while decellularization and 3D printing rely on bioreactors for the maturation of the bioengineered constructs, with this technology, the organs develop in utero, which presents the most convenient and physiologically appropriate conditions.

However, some issues related to the generation of interspecies blastocyst complementation derived organs need to be faced. The purity of the generated organs, in terms of cell composition, need to be addressed. In fact, endothelial cells or other cell types derived from the host could contaminate the donor-derived organ. In addition to the technical problems, ethical concerns has been emphasized in relation to the possibility that human cells could contribution to the formation of nontargeted organs, such as brain or germ cells, generating chimeric brains or fetuses [109].

Expanding the donor pool by the application of regenerative medicine strategies. The narrowest concept of RM presumes the creation of neotissues from a cell source. This presumptive approach entails addressing barriers that may take decades to overcome including those related to manufacturing practicality, safety, regulation and cost/reimbursement. However, established solid organ transplantation may be considered to already encompass a truly RM approach best illustrated by the successful transplantation of kidneys with severe acute kidney injury and most recently, donation after circulatory death (DCD) heart transplants. These clinical successes have allowed organs historically considered unusable to be successfully transplanted but the approach in each case relies on firstly predictable in-vivo regeneration but in the latter case, actively managed ex-vivo muscle cell regeneration in the context of normothermic reperfusion.

Given the exceptionally successful results of solid organ transplants and the global "mantra" that this excellent selection of treatments is limited only by organ availability, it is possible to reason that managed regenerative treatment of the many thousands of deceased donor organs currently declined for transplant worldwide may represent a rapid route for clinical translation of the variety of regenerative therapies currently being developed. This diverges from the assumption that the generation of functioning neotissue is essential for patient benefit and instead uses regenerative cells 
or alternative therapies to protect the intrinsic regenerative capability of the solid organs from damage and promote its augmented activation, during and after the multifaceted phase of peri-transplant graft injury.

This indication is evidently a major arena of clinical need. Candidate regenerative interventions - with the potential for multiple mechanisms of action - may be more effective and are already in phase 1 studies with particular promise for the application of MSC or pleomorphic regenerative cell populations such as those derived from adipose tissue. The former have been widely administered for immunoregulatory purposes but increasingly the focus of such therapies is more regenerative with a recent study in ex-vivo perfused human livers confirming up to $50 \times 10^{6}$ cells can be delivered safely via the hepatic artery. The latter have been safely administered intra-arterially or intra-portally, without vascular complications in animal models of kidney [110], lung and liver as well as directly into porcine and human coronary arteries [111-113]. These interventions have the added advantage of ex-vivo applicability in the context of organ storage or normothermic machine perfusion. This latter scenario offers the opportunity for regenerative therapy in the context of optimized biodistribution and pre-implantation efficacy/safety assessment.

An alternative RM-based approach may be molecule-based, in spite of the fact that multiple small molecule approaches for the indication that we are herein discussing have already failed to show clinical benefit. While on one hand this failure is likely to reflect the extensive redundancy in mechanisms of peri-transplant injury, on the other hand failure may simply tell us that we have not picked the right drug(s)! Ideally, we should consider molecules possessing high regenerative potential rather than molecules that target this or that pathway of the inflammatory response complicating ischemia-reperfusion. For instance, recent groundbreaking work from MDI Biological Laboratories identified MSI-1436 as a first-in-class regenerative medicine drug candidate [114]. In fact, in adult zebrafish, administration of MSI-1436 stimulated the rate of regeneration of caudal fin tissue and heart muscle by 2-3-fold without apparent tissue overgrowth or malformation. Moreover, administration of the drug to adult mice for 4 weeks beginning $24 \mathrm{~h}$ after inducing cardiac ischemia increased survival, improved heart function, reduced infarct size, reduced ventricular wall thinning and increased cellular proliferation in the infarct border zone. In a Phase 1 and $1 \mathrm{~b}$ clinical trials attesting the potential of MSI-1436 for treating obesity and diabetes, good tolerability was demonstrated, and it was found that doses effective at stimulating regeneration were 5-50-times lower than the maximum well tolerated human dose; hence, this molecule shows great promise for applications in multiple TM scenarios.

Given the major financial effects associated with delayed graft function of solid organ transplants, regenerative therapies in this context may also find a role in reducing peri-transplant injury and augmenting post implantation regeneration even in those solid organs currently utilized for transplant. 


\section{Product development challenges for cell-based therapies}

a. Scaling-up production. The scaling up of cell production is not a trivial process as the physical environment where the bioengineered tissue will be implanted will exert a number of known and unknown effects on the physiologic and phenotypic characteristic of the final product. The type, dimension and material where cells are grown is known to impact their characteristic including cell proliferation rate and differentiation potential. Using standardized modular unit in parallel is usually the simplest and safest approach to scaling up from laboratory to industrial production for products dedicated to single individuals. However, this approach result also in an increase of cost, labor and risk of failure for single units (http://www.bioprocessintl.com/manufacturing/celltherapies/streamlining-cell-therapy-manufacture-328083/).

As illustrated above, the integration in a tridimensional structure of different cell types can be obtained using ECM as an instructing guide. However, the timing, composition and degree of differentiation of the cell populations used to regenerate the cellular compartment of these structure remains unclear, as well as the stimuli needed to obtain a complete differentiation before (or after) implantation. Due to the complexity of the function of complex modular organs like the kidney or the heart [115], the issue of scaling out is depending on the ability to replicate the essential manufacturing characteristics in different physical location and/or time. This in turns depends on the ability to identify the key factors regulating the consistency of the manufacturing process and control them [116](https://nam.edu/manufacturing-cell-therapies-the-paradigm-shift-in-health-care-of-thiscentury/). Single use modular apparatus are likely to be the simplest answer to this particular need.

Assessing a complex construct requires the understanding of the specific characteristic desired for any given clinical application and the technologies to measure them. Both non-invasive approaches and surrogate biomarkers will have to be developed in order to perform the identity qualification of the final product, both in terms of functionality and expected half-life after transplantation. However, while it is possible to standardize production, it may be difficult to apply the principle of "one-size-fits-all" to the recipient due to the intrinsic inter-individual variability but also to environmental effects. Adaptation of the process to a finite number of possible recipients is likely to be a necessary step.

b. Key attributes of proposed RM interventions/products that demonstrate their readiness to be advanced into clinical trials.

\section{1) Critical quality attributes}

In order to progress to application in humans, any new RM product should have a clear indication in terms of expected functions in vivo, the definition of surrogate biomarkers for the estimation of the efficacy and an imaging technology to assess the integration and biodistribution. The expected halflife in vivo should be clear, and remedial approaches in case of failure should be well defined. The 
choice of parameters defining the products (i.e. identity) should be justified by a risk assessment and the intended

use (https://www.fda.gov/downloads/BiologicsBloodVaccines/GuidanceComplianceRegulatoryInformati on/Guidances/CellularandGeneTherapy/ucm081670.pdf and http://www.ema.europa.eu/docs/en GB/document library/Scientific guideline/2009/10/WC5000039 87.pdf).

\section{2) Critical process parameters}

The critical process parameters are strictly depending on the cell type and need to cover basic safety and efficacy in vivo after transplantation. Both donor and recipient characteristics should be included in the evaluation of these parameters. Usually these parameters encompass at least cell number, viability and proliferative index, which per se do not exclude the necessity of more specific biomarker testing.

\section{3) Material attributes}

As the cells respond in a complex - yet, still not fully understood - manner to the materials present in the culture media and containers used during the manufacturing process, any substitution or alteration has to be carefully assessed against the panel of final desired characteristics. Depending on their complexity, such assurance could be obtained by either testing the materials before accepting them for the manufacturing process, or by the full qualification of the supply chain. A strict definition of the materials sourcing should be established early in the development process.

\section{c. What are the key regulatory science questions that should be addressed in the next five years?}

The understanding of the expansion limit of the different stem cell lines with potential for clinical applications is the first knowledge gap to be filled. Stem cells should be expanded and harvested without incurring in genomic alterations that would obviously undermine safety. Such limit is now defined in a conservative way for MSC [117] but remains unclear for ESC and iPS. However, the necessity to obtain and qualify new donor cell population regularly constitute a strong limitation to the application on a large scale of RM.

Information about the stability of the transplanted organ/tissue and its response to environmental stimuli in vivo is fundamental for progress in the field but will be obtained only after a more substantial number of applications will be done. Currently, it is not possible to predict the fate of an artificial tissue in vivo, which could engraft permanently while exerting (some) function, but may also fail in time, or be colonized and replaced by endogenous cell. The long-term stability and the ability to exert (to some extent) physiological function(s) after implantation will therefore have to be determined. In this scenario, it will be critical for authors to disclose with honesty and integrity not 
only short- or mid-term results, but also the long-term results. On their side, journals should require authors to provide outcome updates on a regular basis.

As discussed above, so far it has been common practice to implant bioengineered tissues without the reconnection to the blood stream of the recipient or the nervous system. For solid organs or vascularized composite allografts, this is not an option. Therefore, research should devise strategies to allow the integration of the vascular and nervous system of the host with the bioengineered tissue.

\section{Regenerative immunology}

One of the most critical questions to answer is how the immune system could react against a bioengineered cellular construct and if it would be possible to modulate this response [118]. A bioengineered construct consists of two components, the cellular compartment and the cell-supporting system, namely the ECM. While a fully developed lab-grown organ consisting in well differentiated cells deriving from a genetically different donor will certainly be subjected to the same well codified immune response as an allograft, it was initially speculated that tissues derived from allogeneic pluripotent stem cells (PSCs)- were not immunogenic and could therefore evade allorecognition [119]. This hypothesis was based on the observation that primordial cells like PSC present low MHC expression and immunogenicity, and that lab-engineered biological constructs lack dendritic cells and a lymphatic system that are primary drivers of alloimmune response. However, a growing body of literature has clearly shown that PSC are not immune privileged and that even tissues derived from autologous iPS may elicit an inflammatory reaction and succumb to rejection [119]. Therefore, strategies to promote local or systemic tolerance or immunomodulation are currently under investigations. One approach to solve the problem of graft immunogenicity is the cloaking of labgrown (allo- or auto-) grafts in immune-neutral substances, such as nanofilms [120-123]. Alternatively, researchers are assessing whether the constitutive secretion of immune-modulating cytokines, including TGF-beta, by tissues differentiated from PSC promotes polarization of infiltrating $\mathrm{T}$ cells toward a regulatory $\mathrm{T}$ cell (Treg), immune modulatory phenotype [119, 124-126]. Interestingly enough, natural ECM-based scaffolds obtained from human organs that are being used as supporting scaffolding material for bioengineered tissues, have been reported to contain significant amount of TGF-beta [127-130] and to be able to induce T-cell apoptosis and promote conversion of naïve $\mathrm{CD} 4^{+} \mathrm{T}$ cells into $\mathrm{CD} 4^{+} \mathrm{CD} 25^{+} \mathrm{Foxp}^{+}{ }^{+}$Treg $[118,129]$. This observation is consistent with the evidence showing that the ECM possesses strong immunomodulatory properties. Studies in rats showed that rabbit acellular decellularized muscle scaffolds down-regulated $\mathrm{T}$ cell xenogeneic responses and $\mathrm{T}_{\mathrm{H}} 1$ effector function compared to fresh tissue by inducing a state of peripheral $\mathrm{T}$ cell hyporesponsiveness [131]. Moreover, ECM obtained from human normal or diseased organs, promote a protolerogenic macrophage polarization similar to the one that is observed in the adaptive regenerative healing response whereby a phenotypic transition from the pro-inflammatory M1 to the 
immune-modulating M2 phenotype occurs [128, 132, 133]. Therefore, combining the intrinsic ability of PSC-differentiated tissue to release TGF-beta with the immunomodulatory properties of ECMbased scaffolds, may represent a valuable strategy to reduce immunogenicity of bioengeneered organs.

\section{Conclusions}

The transplant era began in 1902 in Vienna, with the successful autotransplantation of a kidney in the neck of a dog performed by Hungary born surgeon Emerich Ullman who however did not succeed in performing any transplant in humans. It took fifty-two years before the first successful renal transplant could be executed in humans, and more than seven decades before transplantation became standard of care for a myriad of clinical settings requiring replacement surgery. In the past few decades, a new field of health science referred to as RM has shown potential to deliver to the bedside organs manufactured from patient's own cells thus bypassing allorecognition and ultimately rendering anti-rejection medication unnecessary. In doing so, RM promises to meet the more urgent needs of our field, proposes a new Holy Grail for modern TM[1] and identifies a field of investigation of immense interest to transplantation (Figure 1).

Few patients have truly benefited from the successful implantation of bioengineered organs, while in the majority of others the graft did not work. Moreover, the anatomical and physiological complexities of modular organs like the liver, the kidney etc., has not been replicated yet and a lot of work remains to be done before organ bioengineering will approach the bedside and so change the paradigm that has dominated transplant medicine for more than a century using lab-grown organs rather than organs procured from deceased or living donors. However, the proof of concept has been provided and researchers are now studying how to fully develop its potential and allow translation. Despite the road to the ultimate objective appears long, winding and difficult (Figure 2), the different RM technologies are still immature and several questions will have to be answered before translation may occur (Table 1), the days when success will be the usual outcome are ahead of us and closer are the days when TM, a discipline that traditionally has been immunology-based [134, 135], will realize that RM should become its major research core. If we agree on this, then TM should allocate more funds to RM-inspired research, transplant societies should twin with RM societies and established RM community of practices and committees, transplant journals and conferences should grant the due consideration and visibility to RM manuscripts. The good news is that most of this is already being done.

To the authors of the present manuscript, it is clear that no field in health sciences has more interest than organ transplantation in fostering progress in RM simply because the future of no other field more than the future of TM will be determined and forged by progress occurring in RM. 
Figure 1. In the history of organ transplantation, we identify three phases or eras. The first can be referred to as the surgery phase and spans from the early days to the advent of cyclosporine. The introduction of this potent immunosuppressant allowed transplantation to become a lifesaving procedure for a myriad of clinical scenarios characterized by irreversible organ failure. The second phase (immunology) spans from the advent of cyclosporine to nowadays. During that phase, we have learned how to manage anti-rejection medications and their impact on patient's quality of life. Importantly, given the burden of side effects that comes with lifelong immunosuppression, we have realized that we should devise strategies to minimize the immunosuppression if not withdrawing it completely sometime after the transplant. Unfortunately, immunosuppression-free transplantation remains unrealistic, despite intense research and multiple attempts to translate promising laboratory findings into the clinic[136, 137]. The third phase has just begun and can be referred to as the regenerative medicine phase. RM promises to meet the most urgent needs of modern transplantation, namely, the identification of a new potentially inexhaustible source of organs and immunosuppression-free transplantation (adapted from Salvatori et al. Xenotransplantation 2015 and Orlando G. Transplantation 2017, with permission).

Figure 2. Roadmap for ex vivo solid organ bioengineering using decellularization and 3D printing technologies. The figure briefly summarizes the milestones to reach on the path towards the Holy Grail. However, the cartoon does not contemplate interspecies blastocyst complementation, which - to the authors - bears the greatest potential for the field because all steps of organ ontogenesis occur in vivo and are strictly regulated by the surrogate animal, without any need for any intervention from the outside. Instead, based on current views, in the case of decellularization and 3D printing, cells and supporting scaffolding materials need to go through a maturation phase whose duration, dynamic and physiology remain largely unknown. 
Table 1. State of the art, perspective and hurdles to overcome in the major RM technologies of transplant interest.

Legend: ECMs extracellular matrix scaffolds; aECMs acellular ECMs; iPSC induced pluripotent stem cells; IBC interspecies blastocyst complementation; GLP good laboratory practice

\begin{tabular}{|c|c|c|}
\hline & State of the art & $\begin{array}{l}\text { Perspective and hurdles to } \\
\text { overcome }\end{array}$ \\
\hline DECELLULARIZATION & $\begin{array}{l}\text { 1. Virtually all organs from } \\
\text { all clinically relevant } \\
\text { mammalian species } \\
\text { including humans can be } \\
\text { decellularized to obtain } \\
\text { acellular ECMs } \\
\text { 2. aECMs preserves most yet } \\
\text { not all molecular and } \\
\text { physical characteristics of } \\
\text { the innate ECM, as the } \\
\text { decellularization process } \\
\text { damages the ECM to an } \\
\text { extent that depends on the } \\
\text { method and the organ } \\
\text { 3. Partial regeneration of the } \\
\text { endothelial and } \\
\text { parenchymal } \\
\text { compartments has been } \\
\text { reported, yet results are } \\
\text { inconsistent and difficult } \\
\text { to reproduce } \\
\text { The maturation phase } \\
\text { reported in the literature } \\
\text { for the different organs } \\
\text { was always far inferior to } \\
\text { the time needed in utero to } \\
\text { develop the organs in } \\
\text { questions } \\
\text { The implantation in vivo } \\
\text { of a viable and } \\
\text { functioning bioengineered } \\
\text { organ has never been } \\
\text { reported }\end{array}$ & $\begin{array}{l}\text { 1. In-depth understanding } \\
\text { of the mechanisms } \\
\text { underlying organ } \\
\text { development, } \\
\text { regeneration and } \\
\text { homeostasis } \\
\text { 2. In-depth understanding } \\
\text { of the mechanisms of } \\
\text { ECM-cell interactions } \\
\text { 3. Cell selection for } \\
\text { recellularization } \\
\text { 4. Harmonious } \\
\text { harnessing of } \\
\text { lymphatic, nervous and } \\
\text { vascular components } \\
\text { 5. Improving the design } \\
\text { of ad hoc bioreactors } \\
\text { to support maturation } \\
\text { 6. Strategies to achieve } \\
\text { adequate } \\
\text { recellularization }\end{array}$ \\
\hline $3 \mathrm{D}$ & $\begin{array}{l}\text { 1. Successful isolation and } \\
\text { expansion of many } \\
\text { functional and supportive } \\
\text { cell types } \\
\text { 2. Replication of mechanical } \\
\text { and biophysical properties }\end{array}$ & $\begin{array}{l}\text { 1. Production of an } \\
\text { adequate number of } \\
\text { regeneration- } \\
\text { competent cells that do } \\
\text { not elicit an immune } \\
\text { repose following }\end{array}$ \\
\hline
\end{tabular}




\begin{tabular}{|c|c|c|}
\hline & $\begin{array}{l}\text { of simple tissues at the } \\
\text { macro-level } \\
\text { 3. Bioprinting of cells with } \\
\text { natural and synthetic } \\
\text { biomaterials with high } \\
\text { resolution } \\
\text { 4. Implantation and in vivo } \\
\text { maturation of small } \\
\text { avascular tissues }\end{array}$ & $\begin{array}{l}\text { transplantation } \\
\text { 2. ECM-based materials } \\
\text { that provide much } \\
\text { stronger mechanical } \\
\text { strength while } \\
\text { maintaining the cell- } \\
\text { supportive } \\
\text { environment } \\
\text { 3. Improvements in } \\
\text { speed, resolution, } \\
\text { material flexibility and } \\
\text { scalability of } \\
\text { bioprinters } \\
\text { Bioprinting of multi- } \\
\text { scale vascular } \\
\text { networks within } \\
\text { instructive bioink that } \\
\text { promotes angiogenic } \\
\text { sprouting and } \\
\text { neovascularization }\end{array}$ \\
\hline iPSCs & $\begin{array}{l}\text { 1. Generation of various } \\
\text { types of complex } \\
\text { organoids in vitro (e.g., } \\
\text { renal, liver, heart, } \\
\text { pancreas) from human } \\
\text { iPSCs } \\
\text { 2. Generation of human } \\
\text { pancreatic tissue in vivo } \\
\text { following transplantation } \\
\text { of iPSC-derived organoids } \\
\text { in mice } \\
\text { 3. iPSCs can be generated } \\
\text { from individual patients, } \\
\text { circumventing the need } \\
\text { for immunosuppressants } \\
\text { following transplantation } \\
\text { into patients }\end{array}$ & $\begin{array}{l}\text { 1. iPSC-derived } \\
\text { organoids typically } \\
\text { resemble foetal } \\
\text { tissues/organs and are } \\
\text { unlikely to mature into } \\
\text { functioning adult } \\
\text { organs } \\
\text { 2. iPSC-derived } \\
\text { organoids generated in } \\
\text { vitro do not have the } \\
\text { blood vessels, } \\
\text { lymphatics and } \\
\text { neuronal innervation } \\
\text { required for them to } \\
\text { function in vivo }\end{array}$ \\
\hline IBC & $\begin{array}{l}\text { 1. Development of } \\
\text { functional rat pancreata } \\
\text { following IBC of Pdx1-/- } \\
\text { mouse blastocysts } \\
\text { 2. Generation of a biallelic } \\
\text { knockout in pigs using } \\
\text { nuclease-based genome } \\
\text { editing shows it could be } \\
\text { possible to generate pig } \\
\text { embryos for IBC that lack } \\
\text { specific organs }\end{array}$ & $\begin{array}{l}\text { 1. To improve the } \\
\text { efficiency of } \\
\text { generating human-pig } \\
\text { chimeric embryos, we } \\
\text { need a greater } \\
\text { understanding of how } \\
\text { the status of human } \\
\text { iPSCs (ie, whether } \\
\text { they are 'naïve', } \\
\text { 'primed' or } \\
\text { 'intermediate') affects }\end{array}$ \\
\hline
\end{tabular}




\begin{tabular}{|c|c|c|}
\hline & $\begin{array}{l}\text { 3. Development of mouse- } \\
\text { human and pig-human } \\
\text { chimeric embryos using } \\
\text { 'primed' human iPSCs }\end{array}$ & $\begin{array}{l}\text { their ability to } \\
\text { integrate into post- } \\
\text { implantation pig } \\
\text { embryos } \\
\text { 2. The contribution of } \\
\text { human iPSCs to } \\
\text { developing pig } \\
\text { embryos is limited and } \\
\text { it has not yet been } \\
\text { possible to generate } \\
\text { human organs using } \\
\text { IBC } \\
\text { 3. Even if the above } \\
\text { challenges were } \\
\text { addressed, a further } \\
\text { problem is that human } \\
\text { organs developed } \\
\text { using IBC would have } \\
\text { pig blood vessels, } \\
\text { lymphatics and } \\
\text { neuronal innervation, } \\
\text { which would probably } \\
\text { lead to immune- } \\
\text { rejection. }\end{array}$ \\
\hline RM for IR & $\begin{array}{l}\text { 1. Multiple candidate cell } \\
\text { populations showing } \\
\text { efficacy beyond previous } \\
\text { small molecule } \\
\text { alternatives. } \\
\text { 2. Emerging evidence of } \\
\text { favourable biodistribution } \\
\text { avoiding off-site effects } \\
\text { 3. Natural organ architecture } \\
\text { available in transplant } \\
\text { context. } \\
\text { 4. Complementary benefits } \\
\text { with normothermic, ex- } \\
\text { vivo perfusion. }\end{array}$ & $\begin{array}{l}\text { 1 Obtaining adequate numbers } \\
\text { of point of care derived } \\
\text { autologous cells. } \\
\text { 2. Obtaining adequate } \\
\text { numbers of efficacious, non- } \\
\text { immunogenic GLP } \\
\text { manufactured allogeneic cells. } \\
\text { 3. Reassurance regarding } \\
\text { potential } \\
\text { vascular/microvascular } \\
\text { complications }\end{array}$ \\
\hline
\end{tabular}




\section{References}

[1] G. Orlando, S. Soker, R.J. Stratta, Organ bioengineering and regeneration as the new Holy Grail for organ transplantation, Ann Surg 258(2) (2013) 221-32.

[2] M. Rela, I. Kaliamoorthy, M.S. Reddy, Current status of auxiliary partial orthotopic liver transplantation for acute liver failure, Liver Transpl 22(9) (2016) 1265-74.

[3] C. Mason, P. Dunnill, A brief definition of regenerative medicine, Regen Med 3(1) (2008) 1-5.

[4] G. Orlando, K.J. Wood, R.J. Stratta, J.J. Yoo, A. Atala, S. Soker, Regenerative medicine and organ transplantation: past, present, and future, Transplantation 91(12) (2011) 1310-7.

[5] S.F. Badylak, D. Taylor, K. Uygun, Whole-organ tissue engineering: decellularization and recellularization of three-dimensional matrix scaffolds, Annu Rev Biomed Eng 13 (2011) 27-53.

[6] S.F. Badylak, D.J. Weiss, A. Caplan, P. Macchiarini, Engineered whole organs and complex tissues, Lancet 379(9819) (2012) 943-52.

[7] S.F. Badylak, J.L. Dziki, B.M. Sicari, F. Ambrosio, M.L. Boninger, Mechanisms by which acellular biologic scaffolds promote functional skeletal muscle restoration, Biomaterials 103 (2016) 128-36.

[8] M.J. Elliott, P. De Coppi, S. Speggiorin, D. Roebuck, C.R. Butler, E. Samuel, C. Crowley, C. McLaren, A. Fierens, D. Vondrys, L. Cochrane, C. Jephson, S. Janes, N.J. Beaumont, T. Cogan, A. Bader, A.M. Seifalian, J.J. Hsuan, M.W. Lowdell, M.A. Birchall, Stem-cell-based, tissue engineered tracheal replacement in a child: a 2-year follow-up study, Lancet 380(9846) (2012) 994-1000.

[9] R.O. Hynes, The extracellular matrix: not just pretty fibrils, Science 326(5957) (2009) 1216-9.

[10] L.T. Saldin, M.C. Cramer, S.S. Velankar, L.J. White, S.F. Badylak, Extracellular matrix hydrogels from decellularized tissues: Structure and function, Acta Biomater 49 (2017) 1-15.

[11] G. Orlando, A.C. Farney, S.S. Iskandar, S.H. Mirmalek-Sani, D.C. Sullivan, E. Moran, T.

AbouShwareb, P. De Coppi, K.J. Wood, R.J. Stratta, A. Atala, J.J. Yoo, S. Soker, Production and implantation of renal extracellular matrix scaffolds from porcine kidneys as a platform for renal bioengineering investigations, Annals of surgery 256(2) (2012) 363-70.

[12] J.D. Naranjo, M.E. Scarritt, L. Huleihel, A. Ravindra, C.M. Torres, S.F. Badylak, Regenerative Medicine: lessons from Mother Nature, Regen Med 11(8) (2016) 767-775.

[13] H.C. Ott, T.S. Matthiesen, S.K. Goh, L.D. Black, S.M. Kren, T.I. Netoff, D.A. Taylor, Perfusiondecellularized matrix: using nature's platform to engineer a bioartificial heart, Nat Med 14(2) (2008) 213-21.

[14] S.H. Mirmalek-Sani, G. Orlando, J.P. McQuilling, R. Pareta, D.L. Mack, M. Salvatori, A.C. Farney, R.J. Stratta, A. Atala, E.C. Opara, S. Soker, Porcine pancreas extracellular matrix as a platform for endocrine pancreas bioengineering, Biomaterials 34(22) (2013) 5488-95.

[15] B.J. Jank, J. Goverman, J.P. Guyette, J.M. Charest, M. Randolph, G.R. Gaudette, J.R. Gershlak, M. Purschke, E. Javorsky, R.M. Nazarian, D.A. Leonard, C.L. Cetrulo, W.G. Austen, H.C. Ott, Creation of a Bioengineered Skin Flap Scaffold with a Perfusable Vascular Pedicle, Tissue Eng Part A 23(13-14) (2017) 696-707.

[16] H. Zhou, K. Kitano, X. Ren, T.K. Rajab, M. Wu, S.E. Gilpin, T. Wu, L. Baugh, L.D. Black, D.J.

Mathisen, H.C. Ott, Bioengineering Human Lung Grafts on Porcine Matrix, Annals of surgery (2017). [17] A. Peloso, A. Petrosyan, S. Da Sacco, C. Booth, J.P. Zambon, T. O'Brien, C. Aardema, J. Robertson, R.E. De Filippo, S. Soker, R.J. Stratta, L. Perin, G. Orlando, Renal Extracellular Matrix Scaffolds From Discarded Kidneys Maintain Glomerular Morphometry and Vascular Resilience and Retains Critical Growth Factors, Transplantation 99(9) (2015) 1807-16.

[18] A. Peloso, L. Urbani, P. Cravedi, R. Katari, P. Maghsoudlou, M.E. Fallas, V. Sordi, A. Citro, C. Purroy, G. Niu, J.P. McQuilling, S. Sittadjody, A.C. Farney, S.S. Iskandar, J.P. Zambon, J. Rogers, R.J. Stratta, E.C. Opara, L. Piemonti, C.M. Furdui, S. Soker, P. De Coppi, G. Orlando, The Human Pancreas as a Source of Protolerogenic Extracellular Matrix Scaffold for a New-generation Bioartificial Endocrine Pancreas, Ann Surg 264(1) (2016) 169-79. 
[19] G. Orlando, C. Booth, Z. Wang, G. Totonelli, C.L. Ross, E. Moran, M. Salvatori, P. Maghsoudlou, M. Turmaine, G. Delario, Y. Al-Shraideh, U. Farooq, A.C. Farney, J. Rogers, S.S. Iskandar, A. Burns, F.C. Marini, P. De Coppi, R.J. Stratta, S. Soker, Discarded human kidneys as a source of ECM scaffold for kidney regeneration technologies, Biomaterials 34(24) (2013) 5915-25.

[20] S.E. Gilpin, J.P. Guyette, G. Gonzalez, X. Ren, J.M. Asara, D.J. Mathisen, J.P. Vacanti, H.C. Ott, Perfusion decellularization of human and porcine lungs: bringing the matrix to clinical scale, J Heart Lung Transplant 33(3) (2014) 298-308.

[21] J.P. Guyette, J.M. Charest, R.W. Mills, B.J. Jank, P.T. Moser, S.E. Gilpin, J.R. Gershlak, T. Okamoto, G. Gonzalez, D.J. Milan, G.R. Gaudette, H.C. Ott, Bioengineering Human Myocardium on Native Extracellular Matrix, Circ Res 118(1) (2016) 56-72.

[22] G. Mazza, W. Al-Akkad, A. Telese, L. Longato, L. Urbani, B. Robinson, A. Hall, K. Kong, L. Frenguelli, G. Marrone, O. Willacy, M. Shaeri, A. Burns, M. Malago, J. Gilbertson, N. Rendell, K. Moore, D. Hughes, I. Notingher, G. Jell, A. Del Rio Hernandez, P. De Coppi, K. Rombouts, M. Pinzani, Rapid production of human liver scaffolds for functional tissue engineering by high shear stress oscillation-decellularization, Sci Rep 7(1) (2017) 5534.

[23] G. Mazza, K. Rombouts, A. Rennie Hall, L. Urbani, T. Vinh Luong, W. Al-Akkad, L. Longato, D. Brown, P. Maghsoudlou, A.P. Dhillon, B. Fuller, B. Davidson, K. Moore, D. Dhar, P. De Coppi, M. Malago, M. Pinzani, Decellularized human liver as a natural 3D-scaffold for liver bioengineering and transplantation, Sci Rep 5 (2015) 13079.

[24] P. Macchiarini, P. Jungebluth, T. Go, M.A. Asnaghi, L.E. Rees, T.A. Cogan, A. Dodson, J. Martorell, S. Bellini, P.P. Parnigotto, S.C. Dickinson, A.P. Hollander, S. Mantero, M.T. Conconi, M.A. Birchall, Clinical transplantation of a tissue-engineered airway, Lancet 372(9655) (2008) 2023-30.

[25] J. Duisit, L. Maistriaux, A. Taddeo, G. Orlando, V. Joris, E. Coche, C. Behets, J. Lerut, C. Dessy, G. Cossu, E. Vogelin, R. Rieben, P. Gianello, B. Lengele, Bioengineering a Human Face Graft: The Matrix of Identity, Annals of surgery (2017).

[26] J. Duisit, H. Amiel, D. Debluts, L. Maistriaux, A. Gerdom, A. Bol, P. Gianello, C. Behets, B. Lengele, Single-Artery Human Ear Graft Procurement: A Simplified Approach, Plast Reconstr Surg 140(3) (2017) 599-603.

[27] J. Duisit, H. Amiel, G. Orlando, A. Dedriche, C. Behets, P. Gianello, B. Lengele, Face Graft Scaffold Production in a Rat Model, Plast Reconstr Surg 141(1) (2018) 95-103.

[28] J. Duisit, H. Amiel, T. Wuthrich, A. Taddeo, A. Dedriche, V. Destoop, T. Pardoen, C. Bouzin, V. Joris, D. Magee, E. Vogelin, D. Harriman, C. Dessy, G. Orlando, C. Behets, R. Rieben, P. Gianello, B. Lengele, Perfusion-decellularization of human ear grafts enables ECM-based scaffolds for auricular vascularized composite tissue engineering, Acta Biomater (2018).

[29] J. Duisit, G. Orlando, D. Debluts, L. Maistriaux, D. Xhema, Y.J. de Bisthoven, C. Galli, A. Peloso, C. Behets, B. Lengele, P. Gianello, Decellularization of the Porcine Ear Generates a Biocompatible, Nonimmunogenic Extracellular Matrix Platform for Face Subunit Bioengineering, Ann Surg 267(6) (2018) 1191-1201.

[30] M. Salvatori, A. Peloso, R. Katari, S. Soker, J.P. Lerut, R.J. Stratta, G. Orlando, Semixenotransplantation: the regenerative medicine-based approach to immunosuppression-free transplantation and to meet the organ demand, Xenotransplantation 22(1) (2015) 1-6.

[31] P. Jungebluth, E. Alici, S. Baiguera, P. Blomberg, B. Bozoky, C. Crowley, O. Einarsson, T. Gudbjartsson, S. Le Guyader, G. Henriksson, O. Hermanson, J.E. Juto, B. Leidner, T. Lilja, J. Liska, T. Luedde, V. Lundin, G. Moll, C. Roderburg, S. Stromblad, T. Sutlu, E. Watz, A. Seifalian, P. Macchiarini, Tracheobronchial transplantation with a stem-cell-seeded bioartificial nanocomposite: a proof-ofconcept study, Lancet 378(9808) (2011) 1997-2004.

[32] A. Gonfiotti, M.O. Jaus, D. Barale, S. Baiguera, C. Comin, F. Lavorini, G. Fontana, O. Sibila, G. Rombola, P. Jungebluth, P. Macchiarini, The first tissue-engineered airway transplantation: 5-year follow-up results, Lancet 383(9913) (2014) 238-44.

[33] I. Fulco, S. Miot, M.D. Haug, A. Barbero, A. Wixmerten, S. Feliciano, F. Wolf, G. Jundt, A. Marsano, J. Farhadi, M. Heberer, M. Jakob, D.J. Schaefer, I. Martin, Engineered autologous cartilage 
tissue for nasal reconstruction after tumour resection: an observational first-in-human trial, Lancet 384(9940) (2014) 337-46.

[34] M. Mumme, A. Barbero, S. Miot, A. Wixmerten, S. Feliciano, F. Wolf, A.M. Asnaghi, D.

Baumhoer, O. Bieri, M. Kretzschmar, G. Pagenstert, M. Haug, D.J. Schaefer, I. Martin, M. Jakob, Nasal chondrocyte-based engineered autologous cartilage tissue for repair of articular cartilage defects: an observational first-in-human trial, Lancet 388(10055) (2016) 1985-1994.

[35] A. Atala, S.B. Bauer, S. Soker, J.J. Yoo, A.B. Retik, Tissue-engineered autologous bladders for patients needing cystoplasty, Lancet 367(9518) (2006) 1241-6.

[36] G. Vogel, Trachea transplants test the limits, Science 340(6130) (2013) 266-8.

[37] P.R. Delaere, D. Van Raemdonck, The trachea: the first tissue-engineered organ?, J Thorac Cardiovasc Surg 147(4) (2014) 1128-32.

[38] S. Badylak, Perspective: Work with, not against, biology, Nature 540(7632) (2016) S55.

[39] P. Tack, J. Victor, P. Gemmel, L. Annemans, 3D-printing techniques in a medical setting: a systematic literature review, Biomed Eng Online 15(1) (2016) 115.

[40] C.L. Ventola, Medical Applications for 3D Printing: Current and Projected Uses, P T 39(10) (2014) 704-11.

[41] X. Cui, K. Breitenkamp, M.G. Finn, M. Lotz, D.D. D'Lima, Direct human cartilage repair using three-dimensional bioprinting technology, Tissue Eng Part A 18(11-12) (2012) 1304-12.

[42] G. Gao, A.F. Schilling, T. Yonezawa, J. Wang, G. Dai, X. Cui, Bioactive nanoparticles stimulate bone tissue formation in bioprinted three-dimensional scaffold and human mesenchymal stem cells, Biotechnol J 9(10) (2014) 1304-11.

[43] J.A. Inzana, D. Olvera, S.M. Fuller, J.P. Kelly, O.A. Graeve, E.M. Schwarz, S.L. Kates, H.A. Awad, 3D printing of composite calcium phosphate and collagen scaffolds for bone regeneration, Biomaterials 35(13) (2014) 4026-34.

[44] D. Hoang, D. Perrault, M. Stevanovic, A. Ghiassi, Surgical applications of three-dimensional printing: a review of the current literature \& how to get started, Ann Transl Med 4(23) (2016) 456.

[45] D.A. Zopf, S.J. Hollister, M.E. Nelson, R.G. Ohye, G.E. Green, Bioresorbable airway splint created with a three-dimensional printer, N Engl J Med 368(21) (2013) 2043-5.

[46] R.J. Morrison, S.J. Hollister, M.F. Niedner, M.G. Mahani, A.H. Park, D.K. Mehta, R.G. Ohye, G.E. Green, Mitigation of tracheobronchomalacia with 3D-printed personalized medical devices in pediatric patients, Sci Transl Med 7(285) (2015) 285 ra64.

[47] G. Gao, A.F. Schilling, K. Hubbell, T. Yonezawa, D. Truong, Y. Hong, G. Dai, X. Cui, Improved properties of bone and cartilage tissue from $3 D$ inkjet-bioprinted human mesenchymal stem cells by simultaneous deposition and photocrosslinking in PEG-GeIMA, Biotechnol Lett 37(11) (2015) 234955.

[48] Y. Yu, K.K. Moncal, J. Li, W. Peng, I. Rivero, J.A. Martin, I.T. Ozbolat, Three-dimensional bioprinting using self-assembling scalable scaffold-free "tissue strands" as a new bioink, Sci Rep 6 (2016) 28714.

[49] H.W. Kang, S.J. Lee, I.K. Ko, C. Kengla, J.J. Yoo, A. Atala, A 3D bioprinting system to produce human-scale tissue constructs with structural integrity, Nat Biotechnol 34(3) (2016) 312-9.

[50] K.J. Burg, S. Porter, J.F. Kellam, Biomaterial developments for bone tissue engineering, Biomaterials 21(23) (2000) 2347-59.

[51] A.C. Daly, G.M. Cunniffe, B.N. Sathy, O. Jeon, E. Alsberg, D.J. Kelly, 3D Bioprinting of Developmentally Inspired Templates for Whole Bone Organ Engineering, Adv Healthc Mater 5(18) (2016) 2353-62.

[52] R.J. Klebe, Cytoscribing: a method for micropositioning cells and the construction of two- and three-dimensional synthetic tissues, Exp Cell Res 179(2) (1988) 362-73.

[53] D.L. Cohen, E. Malone, H. Lipson, L.J. Bonassar, Direct freeform fabrication of seeded hydrogels in arbitrary geometries, Tissue Eng 12(5) (2006) 1325-35.

[54] K. Iwami, T. Noda, K. Ishida, K. Morishima, M. Nakamura, N. Umeda, Bio rapid prototyping by extruding/aspirating/refilling thermoreversible hydrogel, Biofabrication 2(1) (2010) 014108. 
[55] L. Shor, S. Guceri, R. Chang, J. Gordon, Q. Kang, L. Hartsock, Y. An, W. Sun, Precision extruding deposition (PED) fabrication of polycaprolactone (PCL) scaffolds for bone tissue engineering, Biofabrication 1(1) (2009) 015003.

[56] J.A. Barron, P. Wu, H.D. Ladouceur, B.R. Ringeisen, Biological laser printing: a novel technique for creating heterogeneous 3-dimensional cell patterns, Biomed Microdevices 6(2) (2004) 139-47. [57] F. Guillemot, A. Souquet, S. Catros, B. Guillotin, J. Lopez, M. Faucon, B. Pippenger, R. Bareille, M. Remy, S. Bellance, P. Chabassier, J.C. Fricain, J. Amedee, High-throughput laser printing of cells and biomaterials for tissue engineering, Acta Biomater 6(7) (2010) 2494-500.

[58] B. Guillotin, A. Souquet, S. Catros, M. Duocastella, B. Pippenger, S. Bellance, R. Bareille, M. Remy, L. Bordenave, J. Amedee, F. Guillemot, Laser assisted bioprinting of engineered tissue with high cell density and microscale organization, Biomaterials 31(28) (2010) 7250-6.

[59] S.V. Murphy, A. Atala, 3D bioprinting of tissues and organs, Nat Biotechnol 32(8) (2014) 773-85.

[60] B. Derby, Printing and prototyping of tissues and scaffolds, Science 338(6109) (2012) 921-6.

[61] J.O. Hardin, T.J. Ober, A.D. Valentine, J.A. Lewis, Microfluidic Printheads for Multimaterial 3D Printing of Viscoelastic Inks, Adv Mater 27(21) (2015) 3279-84.

[62] T.J. Ober, D. Foresti, J.A. Lewis, Active mixing of complex fluids at the microscale, Proc Natl Acad Sci U S A 112(40) (2015) 12293-8.

[63] W. Wu, A. DeConinck, J.A. Lewis, Omnidirectional printing of 3D microvascular networks, Adv Mater 23(24) (2011) H178-83.

[64] S.J. Hollister, Porous scaffold design for tissue engineering, Nat Mater 4(7) (2005) 518-24.

[65] S. Ji, M. Guvendiren, Recent Advances in Bioink Design for 3D Bioprinting of Tissues and Organs, Front Bioeng Biotechnol 5 (2017) 23.

[66] A. Skardal, J. Zhang, L. McCoard, S. Oottamasathien, G.D. Prestwich, Dynamically crosslinked gold nanoparticle - hyaluronan hydrogels, Adv Mater 22(42) (2010) 4736-40.

[67] W. Zhu, X. Qu, J. Zhu, X. Ma, S. Patel, J. Liu, P. Wang, C.S. Lai, M. Gou, Y. Xu, K. Zhang, S. Chen, Direct 3D bioprinting of prevascularized tissue constructs with complex microarchitecture, Biomaterials 124 (2017) 106-115.

[68] A. Hamm, N. Krott, I. Breibach, R. Blindt, A.K. Bosserhoff, Efficient transfection method for primary cells, Tissue Eng 8(2) (2002) 235-45.

[69] N. Okumura, M. Ueno, N. Koizumi, Y. Sakamoto, K. Hirata, J. Hamuro, S. Kinoshita, Enhancement on primate corneal endothelial cell survival in vitro by a ROCK inhibitor, Invest Ophthalmol Vis Sci 50(8) (2009) 3680-7.

[70] Z. Yu, M. Liu, P. Fu, M. Xie, W. Wang, X. Luo, ROCK inhibition with Y27632 promotes the proliferation and cell cycle progression of cultured astrocyte from spinal cord, Neurochem Int 61(7) (2012) 1114-20.

[71] M.J. Evans, M.H. Kaufman, Establishment in culture of pluripotential cells from mouse embryos, Nature 292(5819) (1981) 154-6.

[72] J.A. Thomson, J. Itskovitz-Eldor, S.S. Shapiro, M.A. Waknitz, J.J. Swiergiel, V.S. Marshall, J.M. Jones, Embryonic stem cell lines derived from human blastocysts, Science 282(5391) (1998) 1145-7. [73] S. Cohen, L. Leshanski, J. Itskovitz-Eldor, Tissue engineering using human embryonic stem cells, Methods Enzymol 420 (2006) 303-15.

[74] M. Malecki, 'Above all, do no harm': safeguarding pluripotent stem cell therapy against iatrogenic tumorigenesis, Stem Cell Res Ther 5(3) (2014) 73.

[75] W. Keung, K.R. Boheler, R.A. Li, Developmental cues for the maturation of metabolic, electrophysiological and calcium handling properties of human pluripotent stem cell-derived cardiomyocytes, Stem Cell Res Ther 5(1) (2014) 17.

[76] M. Baxter, S. Withey, S. Harrison, C.P. Segeritz, F. Zhang, R. Atkinson-Dell, C. Rowe, D.T. Gerrard, R. Sison-Young, R. Jenkins, J. Henry, A.A. Berry, L. Mohamet, M. Best, S.W. Fenwick, H. Malik, N.R. Kitteringham, C.E. Goldring, K. Piper Hanley, L. Vallier, N.A. Hanley, Phenotypic and functional analyses show stem cell-derived hepatocyte-like cells better mimic fetal rather than adult hepatocytes, Journal of hepatology 62(3) (2015) 581-9. 
[77] P. Choudhary, H. Booth, A. Gutteridge, B. Surmacz, I. Louca, J. Steer, J. Kerby, P.J. Whiting, Directing Differentiation of Pluripotent Stem Cells Toward Retinal Pigment Epithelium Lineage, Stem Cells Transl Med 6(2) (2017) 490-501.

[78] S.D. Schwartz, C.D. Regillo, B.L. Lam, D. Eliott, P.J. Rosenfeld, N.Z. Gregori, J.P. Hubschman, J.L. Davis, G. Heilwell, M. Spirn, J. Maguire, R. Gay, J. Bateman, R.M. Ostrick, D. Morris, M. Vincent, E. Anglade, L.V. Del Priore, R. Lanza, Human embryonic stem cell-derived retinal pigment epithelium in patients with age-related macular degeneration and Stargardt's macular dystrophy: follow-up of two open-label phase 1/2 studies, Lancet 385(9967) (2015) 509-16.

[79] S. Grealish, E. Diguet, A. Kirkeby, B. Mattsson, A. Heuer, Y. Bramoulle, N. Van Camp, A.L. Perrier, P. Hantraye, A. Bjorklund, M. Parmar, Human ESC-derived dopamine neurons show similar preclinical efficacy and potency to fetal neurons when grafted in a rat model of Parkinson's disease, Cell Stem Cell 15(5) (2014) 653-65.

[80] Y. Jiang, B.N. Jahagirdar, R.L. Reinhardt, R.E. Schwartz, C.D. Keene, X.R. Ortiz-Gonzalez, M. Reyes, T. Lenvik, T. Lund, M. Blackstad, J. Du, S. Aldrich, A. Lisberg, W.C. Low, D.A. Largaespada, C.M. Verfaillie, Pluripotency of mesenchymal stem cells derived from adult marrow, Nature 418(6893) (2002) 41-9.

[81] M. Dominici, K. Le Blanc, I. Mueller, I. Slaper-Cortenbach, F. Marini, D. Krause, R. Deans, A. Keating, D. Prockop, E. Horwitz, Minimal criteria for defining multipotent mesenchymal stromal cells. The International Society for Cellular Therapy position statement, Cytotherapy 8(4) (2006) 315-7. [82] M. Zang, Q. Zhang, E.I. Chang, A.B. Mathur, P. Yu, Decellularized tracheal matrix scaffold for tracheal tissue engineering: in vivo host response, Plast Reconstr Surg 132(4) (2013) 549e-559e. [83] D. Cyranoski, Investigations launched into artificial tracheas, Nature 516(7529) (2014) 16-7. [84] T.S. de Windt, L.A. Vonk, I.C.M. Slaper-Cortenbach, R. Nizak, M.H.P. van Rijen, D.B.F. Saris, Allogeneic MSCs and Recycled Autologous Chondrons Mixed in a One-Stage Cartilage Cell Transplantion: A First-in-Man Trial in 35 Patients, Stem Cells (2017).

[85] A.I. Caplan, Mesenchymal Stem Cells: Time to Change the Name!, Stem Cells Transl Med 6(6) (2017) 1445-1451.

[86] I. Santeramo, Z. Herrera Perez, A. Illera, A. Taylor, S. Kenny, P. Murray, B. Wilm, N. Gretz, Human Kidney-Derived Cells Ameliorate Acute Kidney Injury Without Engrafting into Renal Tissue, Stem Cells Transl Med 6(5) (2017) 1373-1384.

[87] A. Keating, Mesenchymal stromal cells: new directions, Cell Stem Cell 10(6) (2012) 709-16.

[88] F. Rigo, N. De Stefano, V. Navarro-Tableros, E. David, G. Rizza, G. Catalano, N. Gilbo, F. Maione, F. Gonella, D. Roggio, S. Martini, D. Patrono, M. Salizzoni, G. Camussi, R. Romagnoli, Extracellular Vesicles from Human Liver Stem Cells Reduce Injury in an Ex Vivo Normothermic Hypoxic Rat Liver Perfusion Model, Transplantation 102(5) (2018) e205-e210.

[89] K. Okita, T. Ichisaka, S. Yamanaka, Generation of germline-competent induced pluripotent stem cells, Nature 448(7151) (2007) 313-7.

[90] K. Takahashi, K. Tanabe, M. Ohnuki, M. Narita, T. Ichisaka, K. Tomoda, S. Yamanaka, Induction of pluripotent stem cells from adult human fibroblasts by defined factors, Cell 131(5) (2007) 861-72. [91] A. Cieslar-Pobuda, V. Knoflach, M.V. Ringh, J. Stark, W. Likus, K. Siemianowicz, S. Ghavami, A. Hudecki, J.L. Green, M.J. Los, Transdifferentiation and reprogramming: Overview of the processes, their similarities and differences, Biochim Biophys Acta 1864(7) (2017) 1359-1369.

[92] Y. Shi, H. Inoue, J.C. Wu, S. Yamanaka, Induced pluripotent stem cell technology: a decade of progress, Nat Rev Drug Discov 16(2) (2017) 115-130.

[93] A. Peloso, R. Tamburrini, L. Edgar, B. Wilm, R. Katari, L. Perin, P. Murray, G. Orlando, Extracellular matrix scaffolds as a platform for kidney regeneration, Eur J Pharmacol 790 (2016) 2127.

[94] J. Wan, Y. Huang, P. Zhou, Y. Guo, C. Wu, S. Zhu, Y. Wang, L. Wang, Y. Lu, Z. Wang, Culture of iPSCs Derived Pancreatic beta-Like Cells In Vitro Using Decellularized Pancreatic Scaffolds: A Preliminary Trial, Biomed Res Int 2017 (2017) 4276928. 
[95] B. Wang, A.E. Jakus, P.M. Baptista, S. Soker, A. Soto-Gutierrez, M.M. Abecassis, R.N. Shah, J.A. Wertheim, Functional Maturation of Induced Pluripotent Stem Cell Hepatocytes in Extracellular Matrix-A Comparative Analysis of Bioartificial Liver Microenvironments, Stem Cells Transl Med 5(9) (2016) 1257-67.

[96] A. Remuzzi, M. Figliuzzi, B. Bonandrini, S. Silvani, N. Azzollini, R. Nossa, A. Benigni, G. Remuzzi, Experimental Evaluation of Kidney Regeneration by Organ Scaffold Recellularization, Sci Rep 7 (2017) 43502.

[97] D.J. Weiss, M. Elliott, Q. Jang, B. Poole, M. Birchall, C. International Society of Cell Therapy Pulmonary Scientific, Tracheal bioengineering: the next steps. Proceeds of an International Society of Cell Therapy Pulmonary Cellular Therapy Signature Series Workshop, Paris, France, April 22, 2014, Cytotherapy 16(12) (2014) 1601-13.

[98] C.R. Butler, R.E. Hynds, C. Crowley, K.H. Gowers, L. Partington, N.J. Hamilton, C. Carvalho, M. Plate, E.R. Samuel, A.J. Burns, L. Urbani, M.A. Birchall, M.W. Lowdell, P. De Coppi, S.M. Janes, Vacuum-assisted decellularization: an accelerated protocol to generate tissue-engineered human tracheal scaffolds, Biomaterials 124 (2017) 95-105.

[99] A.J. Orqueda, C.A. Gimenez, F. Pereyra-Bonnet, iPSCs: A Minireview from Bench to Bed, including Organoids and the CRISPR System, Stem Cells Int 2016 (2016) 5934782.

[100] B. Wilm, R. Tamburrini, G. Orlando, P. Murray, Autologous Cells for Kidney Bioengineering, Curr Transplant Rep 3 (2016) 207-220.

[101] M.R. Dilworth, M.J. Clancy, D. Marshall, C.A. Bravery, P.E. Brenchley, N. Ashton, Development and functional capacity of transplanted rat metanephroi, Nephrol Dial Transplant 23(3) (2008) 871-9. [102] J. Chen, R. Lansford, V. Stewart, F. Young, F.W. Alt, RAG-2-deficient blastocyst complementation: an assay of gene function in lymphocyte development, Proc Natl Acad Sci U S A 90(10) (1993) 4528-32.

[103] Q. Zhou, J. Brown, A. Kanarek, J. Rajagopal, D.A. Melton, In vivo reprogramming of adult pancreatic exocrine cells to beta-cells, Nature 455(7213) (2008) 627-32.

[104] T. Kobayashi, T. Yamaguchi, S. Hamanaka, M. Kato-Itoh, Y. Yamazaki, M. Ibata, H. Sato, Y.S. Lee, J. Usui, A.S. Knisely, M. Hirabayashi, H. Nakauchi, Generation of rat pancreas in mouse by interspecific blastocyst injection of pluripotent stem cells, Cell 142(5) (2010) 787-99.

[105] J. Usui, T. Kobayashi, T. Yamaguchi, A.S. Knisely, R. Nishinakamura, H. Nakauchi, Generation of kidney from pluripotent stem cells via blastocyst complementation, Am J Pathol 180(6) (2012) 241726.

[106] T.W. Theunissen, B.E. Powell, H. Wang, M. Mitalipova, D.A. Faddah, J. Reddy, Z.P. Fan, D. Maetzel, K. Ganz, L. Shi, T. Lungjangwa, S. Imsoonthornruksa, Y. Stelzer, S. Rangarajan, A. D'Alessio, J. Zhang, Q. Gao, M.M. Dawlaty, R.A. Young, N.S. Gray, R. Jaenisch, Systematic identification of culture conditions for induction and maintenance of naive human pluripotency, Cell Stem Cell 15(4) (2014) 471-87.

[107] T.W. Theunissen, M. Friedli, Y. He, E. Planet, R.C. O'Neil, S. Markoulaki, J. Pontis, H. Wang, A. louranova, M. Imbeault, J. Duc, M.A. Cohen, K.J. Wert, R. Castanon, Z. Zhang, Y. Huang, J.R. Nery, J. Drotar, T. Lungjangwa, D. Trono, J.R. Ecker, R. Jaenisch, Molecular Criteria for Defining the Naive Human Pluripotent State, Cell Stem Cell 19(4) (2016) 502-515.

[108] J. Wu, D. Okamura, M. Li, K. Suzuki, C. Luo, L. Ma, Y. He, Z. Li, C. Benner, I. Tamura, M.N. Krause, J.R. Nery, T. Du, Z. Zhang, T. Hishida, Y. Takahashi, E. Aizawa, N.Y. Kim, J. Lajara, P. Guillen, J.M. Campistol, C.R. Esteban, P.J. Ross, A. Saghatelian, B. Ren, J.R. Ecker, J.C. Izpisua Belmonte, An alternative pluripotent state confers interspecies chimaeric competency, Nature 521(7552) (2015) 316-21.

[109] B.S. Freedman, Hopes and Difficulties for Blastocyst Complementation, Nephron 138(1) (2018) 42-47.

[110] Z. Feng, J. Ting, Z. Alfonso, B.M. Strem, J.K. Fraser, J. Rutenberg, H.C. Kuo, K. Pinkernell, Fresh and cryopreserved, uncultured adipose tissue-derived stem and regenerative cells ameliorate ischemia-reperfusion-induced acute kidney injury, Nephrol Dial Transplant 25(12) (2010) 3874-84. 
[111] J.H. Houtgraaf, R. de Jong, K. Kazemi, D. de Groot, T.I. van der Spoel, F. Arslan, I. Hoefer, G. Pasterkamp, S. Itescu, F. Zijlstra, M.L. Geleijnse, P.W. Serruys, H.J. Duckers, Intracoronary infusion of allogeneic mesenchymal precursor cells directly after experimental acute myocardial infarction reduces infarct size, abrogates adverse remodeling, and improves cardiac function, Circ Res 113(2) (2013) 153-66.

[112] J. Bobi, N. Solanes, R. Fernandez-Jimenez, C. Galan-Arriola, A.P. Dantas, L. Fernandez-Friera, C. Galvez-Monton, E. Rigol-Monzo, J. Aguero, J. Ramirez, M. Roque, A. Bayes-Genis, J. SanchezGonzalez, A. Garcia-Alvarez, M. Sabate, S. Roura, B. Ibanez, M. Rigol, Intracoronary Administration of Allogeneic Adipose Tissue-Derived Mesenchymal Stem Cells Improves Myocardial Perfusion But Not Left Ventricle Function, in a Translational Model of Acute Myocardial Infarction, J Am Heart Assoc 6(5) (2017).

[113] T. Ma, J. Sun, Z. Zhao, W. Lei, Y. Chen, X. Wang, J. Yang, Z. Shen, A brief review: adiposederived stem cells and their therapeutic potential in cardiovascular diseases, Stem Cell Res Ther 8(1) (2017) 124.

[114] A.M. Smith, K.K. Maguire-Nguyen, T.A. Rando, M.A. Zasloff, K.B. Strange, V.P. Yin, The protein tyrosine phosphatase $1 \mathrm{~B}$ inhibitor MSI-1436 stimulates regeneration of heart and multiple other tissues, Npj Regen Med 2 (2017).

[115] G. Orlando, P. Baptista, M. Birchall, P. De Coppi, A. Farney, N.K. Guimaraes-Souza, E. Opara, J. Rogers, D. Seliktar, K. Shapira-Schweitzer, R.J. Stratta, A. Atala, K.J. Wood, S. Soker, Regenerative medicine as applied to solid organ transplantation: current status and future challenges, Transpl Int 24(3) (2011) 223-32.

[116] P. De Vos, B.J. De Haan, R. Van Schilfgaarde, Upscaling the production of microencapsulated pancreatic islets, Biomaterials 18(16) (1997) 1085-90.

[117] B.G. Abu Jawdeh, H. Rabb, Delayed kidney allograft function - what does it tell us about acute kidney injury?, Contrib Nephrol 174 (2011) 173-81.

[118] P. Cravedi, S. Farouk, A. Angeletti, L. Edgar, R. Tamburrini, J. Duisit, L. Perin, G. Orlando, Regenerative immunology: the immunological reaction to biomaterials, Transpl Int 30(12) (2017) 1199-1208.

[119] P.J. Fairchild, C. Horton, P. Lahiri, K. Shanmugarajah, T.J. Davies, Beneath the sword of Damocles: regenerative medicine and the shadow of immunogenicity, Regen Med 11(8) (2016) 817829.

[120] L. Brasile, P. Glowacki, J. Castracane, B.M. Stubenitsky, Pretransplant kidney-specific treatment to eliminate the need for systemic immunosuppression, Transplantation 90(12) (2010) 1294-8. [121] L. Brasile, P. Glowacki, B.M. Stubenitsky, Bioengineered skin allografts: a new method to prevent humoral response, ASAIO J 57(3) (2011) 239-43.

[122] L. Brasile, N. Henry, B. Stubenitsky, Underlying Mechanisms of Protection Involved in Immunocloak, Transplantation 101(2) (2017) e49-e56.

[123] G. Orlando, ImmunoCloak as a Paradigm of the Biomaterial Approach to Immunomodulation: Where Regenerative Medicine Meets Organ Transplantation, Transplantation 101(2) (2017) 234-235. [124] P.E. de Almeida, E.H. Meyer, N.G. Kooreman, S. Diecke, D. Dey, V. Sanchez-Freire, S. Hu, A. Ebert, J. Odegaard, N.M. Mordwinkin, T.P. Brouwer, D. Lo, D.T. Montoro, M.T. Longaker, R.S. Negrin, J.C. Wu, Transplanted terminally differentiated induced pluripotent stem cells are accepted by immune mechanisms similar to self-tolerance, Nat Commun 5 (2014) 3903.

[125] N.J. Robertson, F.A. Brook, R.L. Gardner, S.P. Cobbold, H. Waldmann, P.J. Fairchild, Embryonic stem cell-derived tissues are immunogenic but their inherent immune privilege promotes the induction of tolerance, Proc Natl Acad Sci U S A 104(52) (2007) 20920-5.

[126] S.A. Oh, M.O. Li, TGF-beta: guardian of T cell function, J Immunol 191(8) (2013) 3973-9. [127] A. Petrosyan, I. Zanusso, M. Lavarreda-Pearce, S. Leslie, S. Sedrakyan, R.E. De Filippo, G. Orlando, S. Da Sacco, L. Perin, Decellularized Renal Matrix and Regenerative Medicine of the Kidney: A Different Point of View, Tissue Eng Part B Rev (2016). 
[128] A. Petrosyan, S. Da Sacco, N. Tripuraneni, U. Kreuser, M. Lavarreda-Pearce, R. Tamburrini, R.E. De Filippo, G. Orlando, P. Cravedi, L. Perin, A step towards clinical application of acellular matrix: A clue from macrophage polarization, Matrix Biol (2016).

[129] A. Peloso, L. Urbani, P. Cravedi, R. Katari, P. Maghsoudlou, M.E. Fallas, V. Sordi, A. Citro, C. Purroy, G. Niu, J.P. McQuilling, S. Sittadjody, A.C. Farney, S.S. Iskandar, J.P. Zambon, J. Rogers, R.J. Stratta, E.C. Opara, L. Piemonti, C.M. Furdui, S. Soker, P. De Coppi, G. Orlando, The Human Pancreas as a Source of Protolerogenic Extracellular Matrix Scaffold for a New-generation Bioartificial Endocrine Pancreas, Annals of surgery (2015).

[130] A. Peloso, A. Petrosyan, S. Da Sacco, C. Booth, J.P. Zambon, T. O'Brien, C. Aardema, J. Robertson, R.E. De Filippo, S. Soker, R.J. Stratta, L. Perin, G. Orlando, Renal Extracellular Matrix Scaffolds From Discarded Kidneys Maintain Glomerular Morphometry and Vascular Resilience and Retains Critical Growth Factors, Transplantation (2015).

[131] J.M. Fishman, M.W. Lowdell, L. Urbani, T. Ansari, A.J. Burns, M. Turmaine, J. North, P. Sibbons, A.M. Seifalian, K.J. Wood, M.A. Birchall, P. De Coppi, Immunomodulatory effect of a decellularized skeletal muscle scaffold in a discordant xenotransplantation model, Proc Natl Acad Sci U S A 110(35) (2013) $14360-5$.

[132] B.N. Brown, B.M. Sicari, S.F. Badylak, Rethinking regenerative medicine: a macrophagecentered approach, Front Immunol 5 (2014) 510.

[133] B.M. Sicari, J.L. Dziki, B.F. Siu, C.J. Medberry, C.L. Dearth, S.F. Badylak, The promotion of a constructive macrophage phenotype by solubilized extracellular matrix, Biomaterials 35(30) (2014) 8605-12.

[134] A. Peloso, R. Katari, J.P. Zambon, G. Orlando, Sisyphus, the Giffen's paradox and the Holy Grail: time for organ transplantation to transition toward a regenerative medicine-focused type of research, Expert review of clinical immunology 9(10) (2013) 883-5.

[135] J. Rogers, R. Katari, S. Gifford, R. Tamburrini, L. Edgar, M.R. Voigt, S.V. Murphy, D. Igel, S. Mancone, T. Callese, N. Colucci, M. Mirzazadeh, A. Peloso, J.P. Zambon, A.C. Farney, R.J. Stratta, G. Orlando, Kidney transplantation, bioengineering and regeneration: an originally immunology-based discipline destined to transition towards ad hoc organ manufacturing and repair, Expert review of clinical immunology 12(2) (2016) 169-82.

[136] G. Orlando, P. Hematti, R.J. Stratta, G.W. Burke, 3rd, P. Di Cocco, F. Pisani, S. Soker, K. Wood, Clinical operational tolerance after renal transplantation: current status and future challenges, Annals of surgery 252(6) (2010) 915-28.

[137] G. Orlando, S. Soker, K. Wood, Operational tolerance after liver transplantation, Journal of hepatology 50(6) (2009) 1247-57. 